\title{
Yerel Halkın Sürdürülebilir Turizme Yönelik Tutumu: Fethiye Örneği ${ }^{1}$
}

\author{
Dr. Öğr. Üyesi Erkan GÜNEŞ \\ Erzincan Binali Yıldırım Üniversitesi, \\ Turizm ve Otelcilik Meslek Yüksekokulu \\ egunes@erzincan.edu.tr \\ https://orcid.org/0000-0002-9196-3958
}

\author{
Dr. Öğr. Üyesi Gürkan ALAGÖZ \\ Erzincan Binali Yıldırım Üniversitesi, \\ Turizm ve Otelcilik Meslek Yüksekokulu \\ galagoz@erzincan.edu.tr \\ https://orcid.org/0000-0002-7446-6220
}

\author{
Dr. Öğr. Üyesi Abdullah USLU \\ Akdeniz Üniversitesi, Manavgat Turizm \\ Fakültesi \\ auslu@akdeniz.edu.tr \\ https://orcid.org/0000-0002-3660-7096
}

DOI: https://doi.org/10.37847/tdtad.804408
Makale Gönderim Tarihi: 02.10 .2020
Makale Türü: Arasstırma Makalesi Makale Kabul Tarihi: 27.11.2020

\section{Özet}

$\mathrm{Bu}$ araştırmanın amacı, yerel halkın sürdürülebilir turizme yönelik tutumlarının tespit edilmesidir. Bu kapsamda 2017 yılı Mart-Haziran ayları arasında Fethiye'de yaşayan 278 kişiye anket uygulanmıştır. Araştırmada veri toplama aracı olarak Sırakaya-Türk vd., (2008) tarafından geliştirilen Sürdürülebilir Turizm Tutum Ölçeğinden yararlanılmıştır. Fethiye'de yaşayan yerel halk sürdürülebilir turizm gelişimine yönelik algılanan ekonomik faydalar faktörüne en yüksek düzeyde, algılanan sosyal maliyetler faktörüne ise en düşük düzeyde katılım göstermiştir. Yerel halk turizmin ekonomik faydalarını yüksek düzeyde hissederken, turizm gelişimin Fethiye'ye olumsuz sosyal maliyetlerinin düşük düzeyde olduğunu belirtmiştir. Ayrıca katılımcıların turizm sektör deneyimi ve sahip olunan gelir düzeyi ile sürdürülebilir turizme ilişkin tutumları arasında farklılık bulunmaktadır.

Anahtar Kelimeler: Sürdürülebilir Turizm, Yerel Halk, Fethiye.

\section{Local People's Attitude Towards Sustainable Tourism: The Case of Fethiye}

\begin{abstract}
The aim of this research is to determine the attitude of local people towards sustainable tourism. In this context, a questionnaire was applied to 278 people living in Fethiye between March and June 2017. In the research, Sustainable Tourism Attitude Scale, which was developed by Sirakaya-Türk et al. (2008), was used as a data collection tool. Local people living in Fethiye participated in the highest perceived economic benefits factor for sustainable tourism development and the lowest in perceived social costs factor. While local people felt the economic benefits of tourism at a high level, they stated that the negative social costs of tourism development for Fethiye were low. In addition, there is a difference between the participants' experience in the tourism sector and the level of income owned and their attitudes towards sustainable tourism.
\end{abstract}

Keywords: Sustainable Tourism, Local People, Fethiye.

\section{GíRiş}

Turizm, dünyanın en hızlı büyüyen ekonomik sektörlerinden ve en büyük faaliyetlerinden olmakla birlikte birçok gelişmekte olan ülke için ana gelir kaynağını temsil ederek uluslararası ticarette önemli oyunculardan biri haline gelmiştir (Sangkakorn \& Suwannarat, 2013). Dünya genelinde turizm hareketlerine katılan kişi sayısı her geçen gün artmaktadır. Bu durum turizm

\footnotetext{
${ }^{1}$ Bu makale, 2-4 Eylül 2020 tarihlerinde düzenlenen "Kıtalararası Turizm Yönetimi Konferansı"nda sunulan ve bildiriler kitabında özet olarak yer alan bildirinin genişletilmiş ve geliştirilmiş halidir.
} 
sektörünün doğrudan ilişkili olduğu çevre, kültür, ekonomi ve yerel halk üzerinde etkili olmaktadir.

Turizm, yerel topluluklara ekonomik faydalar sağlayarak yoksulluğu azaltmanın etkili bir yolu olsa da, turizm gelişimi geleneksel kültüre zarar verebilir ve bölge sakinlerinin geçim kaynaklarını değiştirebilir. Turizmin gelişmesinin ilk aşamalarında, yerel halk ekonomik fayda sağlamak uğruna sosyal, kültürel ve çevresel faktörler üzerinde olumsuz etkilere maruz kalabilir (Khalid vd., 2019).

Bir turistik destinasyonun çevresi, sosyo-kültürel özellikleri, kaynakları ve miras değerleri, o bölgede turizmin gelişim dönemleri için temel arka plan unsurlarıdır. Turistik destinasyonlarda artan turizm faaliyetleri; turizmin gelişmesine, turizm değerlerinin kaybına yol açacak şekilde turizm ve çevre kaynaklarının aşırı kullanılmasına ve bozulmasına neden olabilir. Bir destinasyondaki turizm gelişimi, yerel halkın/destinasyonun esnekliğine, turistik faaliyet yoğunluğuna ve yerel halkın sosyolojik özelliklerine bağlıdır. Bu nedenle bir destinasyonda turizmin uzun ömürlü olması için yerel halkın ve sosyo-kültürel alanların desteklenmesi konusuna özel önem verilmelidir (Joshi \& Dhyani, 2009, s. 33).

Sürdürülebilirlik, turizm gelişiminin çevresel, ekonomik ve sosyo-kültürel yönlerini ifade etmeli ve uzun vadeli sürdürülebilirliğini garanti etmelidir. Yerel halkın sosyo-kültürel özgünlüğüne sayg1 göstermeli, kültürel mirası ve geleneksel değerleri korumalıdır. Sürdürülebilir turizm gelişimine ulaşmak bir süreçtir. Turizmin etkilerinin sürekli izlenmesi ve gerektiğinde önleyici veya düzeltici önlemlerin alınması gerekmektedir (UNWTO, 2019). Yerel halkın önemli bir paydaş olarak algılanması, gelecekteki turizm gelişiminin başarısının belirlenmesinde çok önemlidir (McCaughey vd., 2018).

Sürdürülebilir turizm gelişimi için yerel halkın desteklenmesi konusunda uzun süreçli çalışmaların yapılması yararlı olacaktır (Lee, 2013). Yerel halkın turizme yönelik tutumlarının anlaşılması, politika yapıcıların ve destinasyon yöneticilerinin halkın turizm gelişimine, önerilen düzenlemelere ve mevzuatlara karşı tepkisini daha iyi ölçmesini sağlayabilir. Bu nedenle, sürdürülebilir turizm gelişimine yönelik yerel halkın tutumlarının değerlendirilmesi, turizm planlamasının geliştirilmesi ve uygulanması için çok önemlidir. Çünkü yerel halkın turizme katılımı, turizm endüstrisinin başarısını veya başarısızlığını belirleyebilir (Sırakaya-Türk vd., 2008).

Sürdürülebilir turizm gelişimi fikri, son yıllarda çevresel, sosyo-kültürel çıkarlar ve ekonomik ihtiyaçlara dayanan etkin bir turizm sektörünün sağlanması için gereklilik olarak ortaya çıkmıştır. $\mathrm{Bu}$ üç faktörün üretebileceği olumlu ve olumsuz etkiler arasında bir denge kurmak için, turizm gelişim sürecinde en önemli paydaş olan yerel halkı dikkate almak gerekir (Muresan vd., 2016).

Turizmin olumsuz etkilerinin en aza indirgenmesi için tüm turizm paydaşlarının çaba harcaması ve birlikte hareket etmesi oldukça önemlidir. Pek çok farklı kesimi olumsuz etkileyebilen turizmin yerel halkın yaşayışı ve kültürü üzerinde doğrudan etkileri olabilmektedir. Bu durumda yerel halkın turizm gelişimini desteklemesi kritik bir yere sahiptir. Turizm gelişiminde ve sürdürülebilir başarı sağlanmasında yerel halkın desteğinin alınması önemlidir. Bu kapsamda Fethiye ilçe merkezinde yaşayan yerel halkın sürdürülebilir turizm tutumlarının ölçülmesi önemli bir turizm destinasyonu olan ve her y1l binlerce turiste ev sahipliği yapan Fethiye'de turizm politika ve planlarına yardımcı olacağından gereklidir.

$\mathrm{Bu}$ çalışmada sürdürülebilir turizm gelişiminde önemli bir paydaş olan yerel halkın sürdürülebilir turizme ilişkin görüşlerinin analiz edilmesi amaçlanmıştır. Bu kapsamda Fethiye ilçe merkezinde yaşayan yerel halkın sürdürülebilir turizme yönelik tutumları tespit edilmeye çalışılarak sürdürülebilir turizm gelişimi ile ilgili plan ve süreçlere katkı sunulmaya çalışılmıştır. Çalışma bu yönü ile Fethiye özelinde özgün bir çalışmadır. Doğru bir turizm gelişiminin planlanmasına yol gösterici olabileceği ve sürdürülebilir turizm politikalarının oluşturulması açısından bölgeye katkı 
sağlayacağı beklenmektedir. Ayrıca bölgesel katkılarının yanı sıra ilgili alana ve araştırmacılara kaynak oluşturması bakımından da literatüre katkı sağlayacağı düşünülmektedir.

\section{SÜRDÜRÜLEBILIIR TURIZMM}

Sürdürülebilir turizm kavramı, daha genel bir kavram olan sürdürülebilir kalkınma kavramından türetilmiştir (Garrod \& Fyall, 1998, s. 200). 1980'lerin sonlarından bu yana sürdürülebilir kalkınma, genel olarak kalkınma çalışmalarında ve özellikle turizm araştırmalarında sıkça kullanılmaktadır (Liu, 2003, s. 459). Sürdürülebilir kalkınma turistlerin ihtiyaçlarını karşılamak, ekonomik büyümeyi hızlandırmak, fiziksel kaynakları korumak, çevreyi korumak ve yerel halkın yaşam kalitesini yükselterek gelecek için fırsatlar sunduğundan turizm sektöründe kapsamlı bir şekilde çalış1lmıştır (Lee, 2013).

Sürdürülebilir turizm, turist, çevre ve yerel halk arasındaki gerginliği azaltmayı amaçlayan bir yaklaşımdır. Doğa ve insanların uzun yıllar bir arada kaliteli bir şekilde yaşayabilmesi için gelişmeyi destekleyen ancak gelişmenin sınırları olduğunu savunan bir yaklaşımdır (Sonuç, 2014, s. 27-28). Sürdürülebilir turizm, gelecek kuşakların ihtiyaçlarını karşılamaktan taviz vermeden turist ve yerel halkın mevcut ihtiyaçlarının karşılanmasının yönetilmesidir (Patterson, 2016, s. 5).

Sürdürülebilir turizm, ziyaretçilerin, sektörün, çevre ve yerel halkın ihtiyaçlarının karşılanmasını ve gelecekte oluşabilecek ekonomik, çevresel ve sosyal etkileri temel alan bir felsefedir (UNEP \& WTO, 2005). Bramwell \& Lane (1993) sürdürülebilir turizmi, turizm sektörü, ziyaretçiler ve turistlere ev sahipliği yapan yerel halk arasındaki karmaşık gerilimleri ve sürtüşmeleri azaltmayı amaçlayan olumlu bir yaklaşım olarak tanımlamıştır (Bramwell \& Lane 1993'den aktaran Garrod \& Fyall, 1998).

Birleşmiş Milletler Çevre Programı ve Dünya Turizm Örgütü’ ne göre (UNEP \& WTO, 2005) uzun vadeli sürdürülebilir turizm gelişimi sağlamak için çevresel, ekonomik ve sosyo-kültürel sürdürülebilirlik ilkeleri arasında denge kurulması ve sürdürülebilir turizmi sağlamak için aşağıdaki ilkelerin uygulanması gerektiğini belirtilmiştir (UNEP \& WTO, 2005);

- Temel ekolojik süreçler devam ettirilerek, doğal kaynaklar ve biyolojik çeşitliliği korumaya yardımcı olunmalı ve turizm gelişiminde kilit bir unsur teşkil eden çevresel kaynaklardan en iyi şekilde yararlanılmal,

- Yerel halkın sosyo-kültürel özgünlüğüne saygı gösterilmeli, kültürel miras ve geleneksel değerlerin korunması desteklenerek kültürler arası anlayış ve hoşgörüye katkıda bulunulmalı,

- İstihdam ve gelir getirici firsatları ile ve yerel halka sosyal hizmetler dahil olmak üzere, tüm paydaşlara adil dağıtılmış sosyo-ekonomik faydalar sunulmalı ve yoksulluğun azaltılmasına katkıda bulunan, sürdürülebilir, uzun vadeli ekonomik operasyonlar sağlanmalıdır.

\section{İLGILİ ÇALIŞMALAR}

Lee (2013) Ciguwetland (Tayvan) yerel halkının sürdürülebilir turizm gelişimi için desteklerini değerlendirmeyi amaçladığ çalışmada yerel halkın katılımının sürdürülebilir turizm gelişimi için kritik önem sahip olduğunu ortaya koymuştur (Lee, 2013). Choi \& Murray (2010) ise Teksas'ta yaşayan yerel halkın sürdürülebilir turizme yönelik tutumlarını analiz etmiştir. Elde edilen bulgulara göre, sürdürülebilir turizmin üç ana unsurunun, yani uzun vadeli planlama, yerel halkın katılımı ve çevresel sürdürülebilirliğin turizme verilen destek ve turizmin olumlu ve olumsuz etkileri ile kritik bir şekilde ilişkili olduğunu ortaya koymuştur.

Huayhuaca vd., (2010) Almanya'da Frankenwald Tabiat Parkı içerisinde ve çevresinde yaşayan yerel halk ile turizm gelişimine yönelik tutumlarını sürdürülebilirliğin ekolojik, ekonomik, kurumsal ve sosyo-kültürel boyutları ile incelenmiştir. Yine aynı bölgede Frankenwald Tabiat Parkı yakınında yaşayan yerel halkın sürdürülebilir turizm gelişimi ile memnuniyetinin 
araştırıldığı çalışmada (Cottrell vd., 2013) algılanan memnuniyetin yerel halkın memnuniyetinin en önemli ölçüsü olduğu ve çevresel, ekonomik, sosyo-kültürel ve kurumsal boyutların memnuniyeti etkilediği sonucuna ulaş1lmıştır.

Duran (2013) Bozcaada destinasyonunda yaşayan yerel halkın sürdürülebilir turizm gelişimine yönelik tutumlarını analiz etmiştir. Araştırmada yerel halk desteğinin, özellikle turizmden fayda sağlama ve sürdürülebilirliğin sağlanmasına yönelik uzun dönem planlama faktörleri arasındaki ilişki düzeyinden, yüksek oranda etkilendiği sonucuna ulaşılmıştır. Dağlı (2018) Akçakoca'da yerel halkın sürdürülebilir turizmin gelişimine yönelik tutumlarını ölçmüştür. Sürdürülebilir turizmin gelişimine yönelik yerel halkın tutumlarına ilişkin çevresel sürdürülebilirlik, planlama, halkın turizme katılımı, ekonomik fayda, algılanan maliyet ve ziyaretçi memnuniyeti şeklinde altı boyutun etkili olduğunu ve araştırmaya katılanların demografik özellikleri ile sürdürülebilir turizmin gelişimine yönelik tutumları arasında anlamlı farklılıkların olduğunu tespit etmiştir.

\section{Fethiye}

Fethiye ismi şehit pilot Yüzbaşı Fethi Bey'den aldığ bilinmekte ayrıca Osmanlı döneminde Meğri (gidilemeyen yer) olarak anılmaktadır (Kültür ve Turizm Bakanlığı, 2017). Fethiye, Akdeniz bölgesinin en batısında, Muğla ilinin doğusunda yaklaşık $125 \mathrm{~km}$. uzaklıkta yer almaktadır. TÜIKK (2020) verilerine göre Fethiye'nin nüfusu 2016 yılında 151 bin 474 kişi, 2017 yılında 153 bin 963 kişi, 2018 yılında 157 bin 745 kişi, 2019 yılında 162 bin 686 kişidir. Muğla'nın en büyük nüfusa sahip ikinci ilçesidir. Yakın komşuları Dalaman, Seydikemer, Çameli ve Kaş ilçeleridir. Muğla yolunun yanı sıra ilçenin sahilden ve yayladan Antalya ile Çameli yolundan Denizli ile karayolu ulaşımı olup, ayrıca $48 \mathrm{~km}$ uzaklıkta bulunan Dalaman Havaalanı ile havayolu ulaşımı bulunmaktadır. Deniz yolu ile turistik günübirlik geziler yapılabileceği gibi feribotlar ile Rodos'a da deniz yolu ulaşımı gerçekleştirilmektedir.

Fethiye, Batı Akdeniz havzası içerisinde sahip olduğu doğal güzellikler ve tarihi çekicilikler ile ön plana çıkmaktadır. Dünyaca ünlü Ölüdeniz, dünyanın en güzel ve en iyi yamaç paraşütü yapılan yeri olan ve bünyesinde çok özel flora ve faunayı barındıran Babadă̆, eski bir Rum Köyü olan Kayaköy, şehir merkezinde bulunan Kral Kaya Mezarları ve Osmanlı Kalesi, Şövalye adası, Saklıkent kanyonu, Cadianda, Tlos ve Xantos antik kenti gibi bir çok tarihi ve doğal çekim merkezleri her yıl yüz binlerce insanın Fethiye'ye gelmesini sağlamaktadır. Belki de Fethiye'yi diğer turistik destinasyonlardan ayıran en önemli özelliği oldukça fazla ve birbirinden güzel koylara, sahillere, adalara ve bakir ormanlara sahip olmasıdır. Kelebekler Vadisi, Gemiler adası ve Afkule, Kabak koyu, Çalış Plajı, Belcekız Plajı, Ölüdeniz plajı, Kıdrak Koyu, Katrancı Koyu, Günlüklü Koyu, Göcek Adası, Zeytin Adası, Domuz Adası, Kızıl Ada, Göbün Koyu, Boncuklu Koyu, Küçük Samanlık ve Büyük Samanlık koyu bunlardan sadece bazılarıdır. Fethiye yerel halkın Yörük yaşantısını devam ettirdiği, güçlü kültürel bağlara sahip olduğu ve yayla kültürünün halen devam ettirildiği ender yerlerden birisidir. Ayrıca ilçede birkaç tane Yörük yaşantısını gösteren müze ve sergi alanı dahi bulunmaktadır.

İlçenin geçim kaynağı tarım ve turizmden sağlanmaktadır. Fethiye'nin sahip olduğu doğal güzellikleri ve 1lıman iklimi sayesinde yerli ve yabancı (7.600 kişi yerleşik yabanc1) (FETAV, 2018) birçok insanın Fethiye'ye yerleşmesine sebep olmuştur. Bu da ilçede son dönemde gayrimenkul fiyatlarının artmasına neden olmuştur. Bu durum 2018 TÜİK verilerine yansımış ve Türkiye' de en fazla gayrimenkul fiyatlarının arttığı yer Muğla ve ilçeleri olmuştur.

Muğla İl Kültür ve Turizm Müdürlüğü (2017) verileri ile Fethiye Belediyesi (2017) y1lı verileri birleştirilerek elde edilen bilgiler neticesinde, Fethiye'de toplamda bakanlık işletme belgeli ve mahalli idarelerden belgeli 809 konaklama tesisi, bu tesislere bağl 20.668 oda ve 42.951 yatak kapasitesi bulunduğu anlaşılmaktadır. TÜRSAB (2017) verilerine göre Fethiye genelinde 180 adet A grubu seyahat acentası bulunmaktadir. Fethiye'ye gelen yerli ve yabanc1 toplam turist sayısı hakkında tam olarak net bir sayı bilinmese de Fethiye Turizm Danışma Bürosu verilerine 
göre 2017 yılında Fethiye'ye 750.000 civarında yabancı turistin ve toplamda 1 buçuk milyon civarında yerli ve yabancı turistin geldiği belirtilmektedir.

\section{YÖNTEM}

\section{Amaç ve Önem}

Turizm gelişim süreçlerinde ve sürdürülebilir turizm yönetiminde yerel halkın önemli bir paydaş olarak görülmesi, turizm gelişiminin başarısında yüksek düzeyde etkilidir. Bu araştırmanın amacı Fethiye ilçe merkezinde yaşayan yerel halkın sürdürülebilir turizm tutumlarının ölçülmesidir. Bir bölgedeki turizm gelişiminin yönetilmesinde yerel halkın desteği ulaşılmak istenen turizm seviyesinin sağlanmasında gereklidir. Fethiye'de yaşayan yerel halkın turizme yönelik tutumlarının anlaşılması, bölgede gerçekleştirilecek plan ve politikalara 1şık tutması ve turizm gelişimine yönelik sağlayacağı katkı bakımından önemlidir. Araştırma amacı doğrultusunda katılımcıların sürdürülebilir turizme yönelik tutumlarının belirlenmesiyle birlikte aşağıdaki hipotezler de test edilecektir.

$\mathrm{H}_{1}$ : Katılımcıların cinsiyetleri ile sürdürülebilir turizm tutumları arasında anlamlı bir farklılık vardir.

$\mathrm{H}_{2}$ : Katılımcıların medeni durumları ile sürdürülebilir turizm tutumları arasında anlamlı bir farkl111k vardır.

$\mathrm{H}_{3}$ : Katılımcıların turizm sektöründe deneyimi ile sürdürülebilir turizm tutumları arasında anlamlı bir farklılık vardir.

$\mathrm{H}_{4}$ : Katılımcıların eğitim düzeyi ile sürdürülebilir turizm tutumları arasında anlamlı bir farklılık vardir.

$\mathrm{H}_{5}$ : Katılımcıların gelir düzeyleri ile sürdürülebilir turizm tutumları arasında anlamlı bir farklılık vardir.

\section{Evren ve Örneklem}

Araştırmanın evrenini 2017 yılında Fethiye ilçe merkezinde yaşayan yerel halk oluşturmaktadır. TÜİK 2016 yılı verilerine göre Fethiye'nin nüfusu 151 bin 474 kişidir. Araştırma 2017 yılı MartHaziran ayları arasında Fethiye ilçe merkezinde kolayda örnekleme yöntemiyle gerçekleştirilmiştir. Bryman ve Cramer (2001) madde sayısının beş ya da onla çarpılmasıyla yeterli örneklem büyüklügünün elde edileceğini ifade etmektedir. Ölçek ifade sayılarının toplamda 33 olduğu çalışmada, eksik ve hatalı anketler çıkarıldıktan sonra 278 anket üzerinden veri analizleri gerçekleştirilmiştir. Toplanan veri sayısının evreni temsil etmede yeterli olduğu ifade edilebilir (Bryman \& Cramer, 2001'den aktaran Gündüz Çetin \& Nalbantoğlu Yılmaz, 2016).

\section{Veri Toplama Araçları}

Araştırmada veri toplama aracı olarak anket tekniği kullanılmıştır. Anket formu iki bölümden oluşmaktadır. İlk bölümde yedi soru bulunmaktadır. Bu soruların altısı araştırmaya katılanların demografik özelliklerini belirlemeye, bir soru ise sürdürülebilir turizmde hangi kurum veya kişilerin en önemli role sahip olduğunu tespit etmeye yöneliktir. İkinci bölüm ise araştırmaya katılanların sürdürülebilir turizme yönelik tutumlarını ölçen 33 ifadeden oluşmaktadır. $\mathrm{Bu}$ bölümdeki ifadeler Sırakaya-Türk vd., (2008) tarafından geliştirilen Sürdürülebilir Turizm Tutum Ölçeği ile oluşturulmuştur. Ölçeğin Türkçe uyarlaması Altıntaş (2010)'dan yararlanılarak oluşturulmuştur. Buradaki ifadeler 1=Hiç Katılmıyorum; 2=Katılmıyorum; 3=Ne Katılıyorum Ne Katılmiyorum; 4=Katıllyorum; 5=Tamamen Katıllyorum şeklinde 5'li likert ile derecelendirilmiştir. Kullanılan veri toplama aracının genel güvenilirlik katsayısı $(\alpha)$ 0,844'dür. Anketin genel güvenilirliğinin yüksek olduğu söylenebilir (Kayış, 2010, s. 405). 


\section{Verilerin Analizi}

Sürdürülebilir turizm tutum ölçeği katılımcıların sürdürülebilir turizmle ilgili tutumlarını ölçmek amaciyla Sırakaya-Türk vd., (2008) amaciyla geliştirilmiştir. Verilerin faktör analizine uygun olup olmadığıyla ilgili yapılan KMO örneklem yeterliliği testinde KMO 0,810 Barlett testi $\left(\mathrm{x}^{2}=\right.$ $3116.512) \mathrm{p}<0.05$ şeklindedir. $\mathrm{KMO}=0.70$ ve üzeri için iyi düzeyde ilişkiyi sağlayacak örneklem yeterliği şeklinde olduğundan verilerin faktör analizine uygun olduğu söylenebilir (Can, 2018, s. 325). Yapılan faktör analizi neticesinde analize giren 33 ifadeden birden fazla faktöre yük veren ve aralarında 0,10 'den az fark bulunan ifadeler analizin dışına çıkarılması tavsiye edildiğinden (Büyüköztürk, 2010, s. 124-125) dokuz ifade analiz kapsamı dışına çıkarılmıştır. Faktör analizi sonucunda 24 ifadeli yedi faktörlü bir yapı ortaya çıkmıştır. Bu sonuç ölçeğin orijinalinde yer alan yedi faktörle uyumludur. Faktör analizi sonucunda; toplum katılımının maksimize edilmesi, çevrenin sürdürülebilirliği, algllanan sosyal maliyetler ve toplum merkezli ekonomi faktörleri dörder ifade, algllanan ekonomik faydalar ve uzun dönem planlama üçer ifade ve ziyaretçi memnuniyetinin sağlanması faktöründe ise iki ifade elde edilmiştir (Tablo 1). Çevrenin sürdürülebilirliği, algılanan ekonomik faydalar, uzun dönem planlama ve toplum merkezli ekonomi faktörlerinden birer ifade, toplum katılımının maksimize edilmesi faktöründen iki ve ziyaretçi memnuniyetinin sağlanması faktöründen üç ifade toplamda dokuz ifade doğru dağılmamıştır.

Tablo 1. Faktör Analizi

\begin{tabular}{|c|c|c|c|c|c|c|c|}
\hline \multirow{2}{*}{ İFADELER } & \multicolumn{7}{|c|}{ Faktörler } \\
\hline & TKME & CS & $\mathbf{A S M}$ & AEF & UDP & TME & ZMS \\
\hline $\begin{array}{l}\text { Toplum bireyleri turizm planlama komitelerinde liderlik } \\
\text { yapmak için teşvik edilir. }\end{array}$ & .773 & & & & & & \\
\hline $\begin{array}{l}\text { Toplum bireylerinin turizm karar mekanizmalarında yer } \\
\text { alabilmeleri için firsatlar yaratılmıştır. }\end{array}$ & .763 & & & & & & \\
\hline $\begin{array}{l}\text { Turizm sektörü her zaman toplumun değer yargılarını } \\
\text { dikkate alır. }\end{array}$ & .700 & & & & & & \\
\hline $\begin{array}{l}\text { Turizmin gelişmesi ile toplumun tüm kurumlarında çevre } \\
\text { bilinci artar. }\end{array}$ & .524 & & & & & & \\
\hline Turizm yaban hayatı ve doğal yaşamı her zaman korur. & & .788 & & & & & \\
\hline $\begin{array}{l}\text { Turizm ile doğal çevremiz hem bugün hem de gelecekte } \\
\text { korunur. }\end{array}$ & & .750 & & & & & \\
\hline Turizm çevreyi korur. & & .729 & & & & & \\
\hline Turizm doğal ve kültürel çevreyle uyum içinde gelişir. & & .624 & & & & & \\
\hline $\begin{array}{l}\begin{array}{l}\text { Bölgemize gelen turistler yaşam kalitemi olumsuz } \\
\text { etkilemektedir. }\end{array} \\
\end{array}$ & & & .838 & & & & \\
\hline Turizm yüzünden kendimi rahatsız hissediyorum & & & .826 & & & & \\
\hline $\begin{array}{l}\text { Turizm yüzünden yaşam kalitemin kötüye gittiğini } \\
\text { hissediyorum. }\end{array}$ & & & .667 & & & & \\
\hline Bölgem turizm gelişimi yüzünden aşırı kalabalıktır. & & & .625 & & & & \\
\hline $\begin{array}{l}\text { Turizmi bölgemize yeni gelir kaynağı yaratması yüzünden } \\
\text { seviyorum. }\end{array}$ & & & & .792 & & & \\
\hline Turizm bölge ekonomisi için iyidir. & & & & .784 & & & \\
\hline Turizm yerel ekonomiyi çeşitlendirir. & & & & .682 & & & \\
\hline Fethiye'de turizm kalkınma planları sürekli geliştirilir. & & & & & .778 & & \\
\hline Turizm sektörü geleceğe yönelik plan yapar. & & & & & .710 & & \\
\hline $\begin{array}{l}\text { Başarılı turizm yönetimi için ileri düzeyde planlama } \\
\text { yapılması gerekir. }\end{array}$ & & & & & 685 & & \\
\hline Turizmden sağlanan gelir halkın geniş kitlelerine dağılır. & & & & & & .769 & \\
\hline
\end{tabular}




\begin{tabular}{|l|l|l|l|l|l|l|l|}
\hline $\begin{array}{l}\text { Turizm sektöründe tüketilen mal ve hizmetlerin büyük } \\
\text { çoğunluğu bölgedeki üretimle karşılanır. }\end{array}$ & & & & & .698 & \\
\hline $\begin{array}{l}\text { Turizm sektörü bölgenin gelişmesi ççin gerekli olan fonlara } \\
\text { katkıda bulunur. }\end{array}$ & & & & & & .521 & \\
\hline $\begin{array}{l}\text { Turizm işletmeleri çalıştıracağı insanların büyük } \\
\text { çoğunluğunu Fethiye ve çevresinden karşılar. }\end{array}$ & & & & & & .471 & \\
\hline Yerel yönetim turist memnuniyetini takip eder. & & & & & & & .868 \\
\hline $\begin{array}{l}\text { Yerel yönetim turistlerin olumlu izlenimlerini } \\
\text { arttırabilmek için yatırım yapar. }\end{array}$ & & & & & & & .804 \\
\hline Faktörlerin güvenilirlik skorları $\alpha$ & .740 & .751 & .742 & .741 & .690 & .640 & .689 \\
\hline Faktörlerin döndürülmüş özdeğerleri & 2.440 & 2.335 & 2.307 & 2.252 & 2.027 & 1.915 & 1.587 \\
\hline Açıklanan varyans oranı & 10.168 & 9.727 & 9.614 & 9.381 & 8.447 & 7.980 & 6.614 \\
\hline Toplam açıklanan varyans oranı & & & & & & \\
\hline Genel güvenilirlik skoru $(\alpha)$ & & & & & \\
\hline
\end{tabular}

TKME: Toplum Katılımının Maksimize Edilmesi. ÇS: Çevrenin Sürdürülebilirliği. ASM: Algılanan Sosyal Maliyetler. AEF: Alg1lanan Ekonomik Faydalar. UDP: Uzun Dönem Planlama. TME: Toplum Merkezli Ekonomi. ZMS: Ziyaretçi Memnuniyetinin Sağlanması

Faktör analizi sonucunda ortaya çıkan yedi faktöre ilişkin normal dağılım sonuçları faktörlerin çarpıklık ve basıklık katsayılarına bakılarak incelenmiştir. Çarpıklık katsayıları $-0.321-1.043$ arasında, basıklık katsayıları ise $0.100-1.195$ arasındadır. Basıklık ve çarpıklık değerleri \pm 1.5 olduğunda verileri normal dağılıma uygun olduğu kabul edilmektedir (Tabachnick \& Fidell, 2013). Veriler normal dağılıma uygun olduğundan verilerin analizinde parametrik hipotez testlerinden yararlanılmışıı. Araştırmada frekans analizi ve ifadelerin ortalamalarına yer verilmiş, hipotez testleri için t-testi ve varyans (ANOVA) analizinden yararlanılmıştır.

\section{BULGULAR}

Tablo 2'de araştırmaya katılanların demografik özelliklerine ilişkin sayısal veriler bulunmaktadır. Tabloya göre araştırmaya katılanların çoğunluğunu (\% 62.9) erkek katılımcılar, \%53.2 si ise bekar katılımcılardan oluşturmaktadır. Araştırmaya katılanların yaş aralıklarına bakıldığında \% 56.8'inin 29 yaşının altında olduğu görülmektedir. Katılımcıların yarısından fazlasının genç olduğu söylenebilir. Katılımcıların gelir düzeylerine bakıldığında \%18.3'ünün geliri yokken, \% 10.8 'i ise 3.001 TL ve üzerinde gelire sahiptir. Katılımcıların \%21'i üniversite mezunu ve \% 65.5 'i ise turizm sektöründe çalıştı̆̆ını belirtmiştir.

Tablo 2. Demografik Bulgular

\begin{tabular}{|l|c|c|l|c|c|}
\hline Cinsiyet & $\mathbf{n}$ & $\mathbf{\%}$ & Gelir & $\mathbf{n}$ & $\mathbf{\%}$ \\
\hline Kadın & 103 & 37.1 & Gelirim yok & 51 & 18.3 \\
\hline Erkek & 175 & 62.9 & $1-1500$ も & 80 & 28.8 \\
\hline Yaş & $\mathbf{n}$ & $\mathbf{\%}$ & $1501-2000$ も & 73 & 26.3 \\
\hline $18-24$ & 79 & 28.4 & $2001-3000$ も & 44 & 15.8 \\
\hline $25-29$ & 79 & 28.4 & 3001 も ve üzeri & 30 & 10.8 \\
\hline $30-39$ & 59 & 21.2 & Ĕgitim & $\mathbf{n}$ & \% \\
\hline $40-49$ & 34 & 12.2 & İlkokul & 20 & 7.2 \\
\hline $50-59$ & 22 & 7.9 & Ortaokul & 45 & 16.2 \\
\hline $60+$ & 5 & 1.8 & Lise & 99 & 35.6 \\
\hline Medeni durum & $\mathbf{n}$ & $\mathbf{\%}$ & Ön lisans & 71 & 25.5 \\
\hline Evli & 130 & 46.8 & Lisans & 43 & 15.5 \\
\hline Bekâr & 148 & 53.2 & Toplam & $\mathbf{2 7 8}$ & $\mathbf{1 0 0}$ \\
\hline Sektör deneyimi & $\mathbf{n}$ & $\mathbf{\%}$ & & & \\
\hline Var & 182 & 65.5 & & & \\
\hline Yok & 96 & 34.5 & & & \\
\hline
\end{tabular}


Tablo 3'de sürdürülebilir turizmde en önemli rolün kime ait olduğuna yönelik yöneltilen soruya katılımcıların verdikleri cevaplar yer almaktadır. Tabloya göre katılımcılar sürdürülebilir turizmde en önemli rolün turizm işletmelerine (\%30.9) ve İl Kültür ve Turizm Müdürlügü’ne (\%28.1) ait olduğunu belirtilmiştir.

Tablo 3. Sürdürülebilir Turizmde En Önemli Role Sahip Paydaşlar

\begin{tabular}{|l|c|c|}
\hline & $\mathbf{n}$ & \% \\
\hline Kaymakamlık & 27 & 9.7 \\
\hline İl Kültür ve Turizm Müdürlüğü & 78 & 28.1 \\
\hline Turizm İşletmeleri & 86 & 30.9 \\
\hline Belediye & 26 & 9.4 \\
\hline Üniversite & 3 & 1.1 \\
\hline Yerel Halk & 16 & 5.8 \\
\hline Turistler & 30 & 10.8 \\
\hline STK & 1 & .4 \\
\hline Diğer & 11 & 4.0 \\
\hline Toplam & $\mathbf{2 7 8}$ & $\mathbf{1 0 0 . 0}$ \\
\hline
\end{tabular}

Ayrıca sürdürülebilir turizmde turistlere de (\%10.8) önemli bir rol düştüğü belirtilmiştir. Araştırmaya katılanların sadece \%5.8 yerel halkın sürdürülebilir turizmde rol oynadığını düşünmektedir. Genele bakıldığında katılımcıların büyük bir kısmı (\%47.2) yerel yönetimlerin (kaymakamlık, il kültür ve turizm müdürlüğü, belediye) sürdürülebilir turizmde en önemli role sahip olduğunu belirtmişlerdir.

Tablo 4'te katılımcıların sürdürülebilir turizm tutum ifadelerine verdikleri cevapların aritmetik ortalamaları verilmiştir. Araştırmada yapılan faktör analizi sonucunda analiz dışına çıkarılan ifadelerde bu tabloda yer almaktadır. Algılanan sosyal maliyetler faktörüne katılım düzeyi $(\overline{\mathrm{x}}=2.06)$ düşüktür. Dolayısıyla Fethiye'de turizm hareketliliğinin sosyal hayat üzerinde olumsuz etkilerinin yoğun bir şekilde hissedilmediği söylenebilir. Çevrenin sürdürülebilirliği faktörüne $(\overline{\mathrm{x}}=3.34)$ ve uzun dönem planlama faktörüne katılım $(\overline{\mathrm{x}}=3.66)$ orta düzeydedir. Turizmin en önemli kaynaklarından birisinin doğal kaynaklar olması nedeniyle çevrenin sürdürülebilirliği tüm destinasyonlar için önemlidir. Yerel halk bu faktördeki ifadelere kararsız bir tutum sergilemiştir.

Tablo 4. Sürdürülebilir Turizm Tutum İfadelerinin Aritmetik Ortalamaları

\begin{tabular}{|l|c|c|}
\hline Algılanan Sosyal Maliyetler & $\overline{\mathbf{x}}$ & \multicolumn{1}{|c|}{ s.s } \\
\hline Turizm yüzünden kendimi rahatsız hissediyorum & 1.69 & 1.01 \\
\hline Bölgemize gelen turistler yaşam kalitemi olumsuz etkilemektedir. & 1.85 & 1.05 \\
\hline Bölgem turizm gelişimi yüzünden aşırı kalabalıktır. & 2.53 & 1.26 \\
\hline Turizm yüzünden yaşam kalitemin kötüye gittiğini hissediyorum. & 2.16 & 1.23 \\
\hline & \multicolumn{2}{|c|}{2.06} \\
\hline Çevrenin Sürdürülebilirliği & $\overline{\mathbf{x}}$ & \multicolumn{1}{|c|}{ S.s } \\
\hline Turizmin gelişimi için doğanın çeşitliliğine değer verilmeli ve korunmalıdır. & 3.86 & 1.30 \\
\hline Turizm çevreyi korur. & 3.16 & 1.28 \\
\hline Turizm yaban hayatı ve doğal yaşamı her zaman korur. & 3.06 & 1.19 \\
\hline Turizm ile doğal çevremiz hem bugün hem de gelecekte korunur. & 3.22 & 1.16 \\
\hline Turizm doğal ve kültürel çevreyle uyum içinde gelişir. & 3.40 & 1.23 \\
\hline & \multicolumn{2}{|c|}{3.34} \\
\hline Uzun Dönem Planlama & $\overline{\mathbf{x}}$ & s.s \\
\hline Fethiye'de turizmin gelişiminin iyi planlandığına inanıyorum. & 3.17 & 1.32 \\
\hline Başarılı turizm yönetimi için ileri düzeyde planlama yapılması gerekir. & 3.87 & 1.13 \\
\hline Fethiye'de turizm kalkınma planları sürekli geliştirilir. & 3.68 & 1.13 \\
\hline
\end{tabular}




\begin{tabular}{|c|c|c|}
\hline Turizm sektörü geleceğe yönelik plan yapar. & 3.92 & 1.02 \\
\hline Genel Ortalama & \multicolumn{2}{|c|}{3.66} \\
\hline Algılanan Ekonomik Faydalar & $\overline{\mathbf{x}}$ & S.S \\
\hline Turizmin bölge ekonomisine büyük katkı sağladığına inanıyorum. & 3.98 & 1.07 \\
\hline Turizm yerel ekonomiyi çeşitlendirir. & 3.92 & 1.11 \\
\hline Turizmi bölgemize yeni gelir kaynağı yaratması yüzünden seviyorum. & 3.97 & 1.03 \\
\hline Turizm bölge ekonomisi için iyidir. & 4.06 & 0.97 \\
\hline Genel Ortalama & \multicolumn{2}{|c|}{3.98} \\
\hline Toplum Merkezli Ekonomi & $\overline{\mathbf{x}}$ & S.S \\
\hline $\begin{array}{l}\text { Turizm işletmeleri çalıştıracağı insanların büyük çoğunluğunu Fethiye ve çevresinden } \\
\text { karşılar. }\end{array}$ & 3.58 & 1.12 \\
\hline Turizmden sağlanan gelir halkın geniş kitlelerine dağılır. & 3.49 & 1.18 \\
\hline $\begin{array}{l}\text { Turizm sektöründe tüketilen mal ve hizmetlerin büyük çoğunluğu bölgedeki üretimle } \\
\text { karşılanır. }\end{array}$ & 3.43 & 1.16 \\
\hline Turizm sektörü bölgenin gelişmesi için gerekli olan fonlara katkıda bulunur. & 3.49 & 1.12 \\
\hline Bölgedeki turizm hareketleri bölgesel mallar için yeni pazarlar yaratır. & 3.67 & 1.02 \\
\hline Genel Ortalama & \multicolumn{2}{|c|}{3.53} \\
\hline Toplum Katılımının Maksimize Edilmesi & $\overline{\mathbf{x}}$ & S.S \\
\hline $\begin{array}{l}\text { Başarılı bir turizm gelişimi için toplumdaki her kesimin turizm karar mekanizmasına } \\
\text { katılımı gereklidir. }\end{array}$ & 3.58 & 1.05 \\
\hline Yerel halka turizm karar mekanizmalarında yer alabilmeleri için firsat verilir. & 3.51 & 1.10 \\
\hline Turizm sektörü her zaman toplumun değer yargılarını dikkate alır. & 3.32 & 1.24 \\
\hline $\begin{array}{l}\text { Toplum bireylerinin turizm karar mekanizmalarında yer alabilmeleri için firsatlar } \\
\text { yaratılmıştır. }\end{array}$ & 3.43 & 1.09 \\
\hline Toplum bireyleri turizm planlama komitelerinde liderlik yapmak için teşvik edilir. & 3.45 & 1.13 \\
\hline Turizmin gelişmesi ile toplumun tüm kurumlarında çevre bilinci artar. & 3.49 & 1.08 \\
\hline Genel Ortalama & \multicolumn{2}{|c|}{3.46} \\
\hline Ziyaretçi Memnuniyetinin Sağlanması & $\overline{\mathbf{x}}$ & S.S \\
\hline Turizm işletmeleri turistlerin memnuniyetini dikkate alır. & 3.79 & 1.16 \\
\hline Turizm turistlerin olumlu izlenimlerle ayrılmalarını sağlar. & 3.67 & 1.08 \\
\hline Doğal çevrenin çekici olması turistler için önemlidir. & 4.05 & 1.08 \\
\hline Yerel yönetim turist memnuniyetini takip eder. & 3.54 & 1.17 \\
\hline Yerel yönetim turistlerin olumlu izlenimlerini arttırabilmek için yatırım yapar. & 3.53 & 1.30 \\
\hline Genel Ortalama & \multicolumn{2}{|c|}{3.72} \\
\hline
\end{tabular}

Yerel halk turizmin gelişmesiyle ekonomik fayda sağlayacağını düşünmekte ve dolayısıyla alg1lanan ekonomik faydalar faktörüne $(\overline{\mathrm{x}}=3.98)$ yüksek, toplum merkezli ekonomi faktörüne ise $(\overline{\mathrm{x}}=3.53)$ orta düzeyde katılım göstermişlerdir. Yerel halkın planlama ve karar almaya katılımını içeren toplum katılımının maksimize edilmesi faktörüne ilişkin katılım ( $\overline{\mathrm{x}}=3.46)$ ve ziyaretçi memnuniyetinin sağlanması faktörüne katılım $(\overline{\mathrm{x}}=3.72)$ orta düzeydedir.

Tablo 5-6-7-8-9 araştırma hipotezlerinin test sonuçlarına ilişkin bulguları içermektedir. Tablo 5 'te katılımcıların cinsiyetleri ile sürdürülebilir turizm tutumları arasında anlamlı farklılık olup olmadı̆̆ına ilişkin t-testi sonuçları verilmiştir. Yapılan t-testi sonucunda katılımcıların sürdürülebilir turizm tutumları ile cinsiyetleri açısından farklılık bulunmamaktadır ( $\mathrm{p}>0.05)$. Bu bilgiler 1şı̆̆ında $H_{1}$ Katılımcıların cinsiyetleri ile sürdürülebilir turizm tutumları arasında anlamlı bir farklılık vardır hipotezi reddedilmiştir. 
Tablo 5. Katılımcıların Cinsiyetleri İle Sürdürülebilir Turizm Tutumlarına İlişkin t-Testi

\begin{tabular}{|c|c|c|c|c|c|c|}
\hline Faktör & Cinsiyet & $\mathbf{n}$ & $\overline{\mathbf{x}}$ & S.S. & $\mathbf{t}$ & p \\
\hline \multirow{2}{*}{ Algılanan Sosyal Maliyetler } & Kadın & 103 & 2.06 & 0.79 & \multirow{2}{*}{-.003} & \multirow{2}{*}{0.998} \\
\hline & Erkek & 175 & 2.06 & 0.88 & & \\
\hline \multirow{2}{*}{ Çevrenin Sürdürülebilirliği } & Kadın & 103 & 3.18 & 0.80 & \multirow{2}{*}{-.489} & \multirow{2}{*}{0.625} \\
\hline & Erkek & 175 & 3.23 & 0.98 & & \\
\hline \multirow{2}{*}{ Uzun Dönem Planlama } & Kadın & 103 & 3.75 & 0.81 & \multirow{2}{*}{-1.171} & \multirow{2}{*}{0.242} \\
\hline & Erkek & 175 & 3.87 & 0.89 & & \\
\hline \multirow{2}{*}{ Algılanan Ekonomik Faydalar } & Kadın & 103 & 3.90 & 0.85 & \multirow{2}{*}{-1.326} & \multirow{2}{*}{0.186} \\
\hline & Erkek & 175 & 4.04 & 0.83 & & \\
\hline \multirow{2}{*}{ Toplum Merkezli Ekonomi } & Kadın & 103 & 3.50 & 0.79 & \multirow{2}{*}{0.033} & \multirow{2}{*}{0.973} \\
\hline & Erkek & 175 & 3.49 & 0.80 & & \\
\hline \multirow{2}{*}{$\begin{array}{l}\text { Toplum Katılımin Maksimize } \\
\text { Edilmesi }\end{array}$} & Kadın & 103 & 3.48 & 0.79 & \multirow{2}{*}{0.799} & \multirow{2}{*}{0.425} \\
\hline & Erkek & 175 & 3.39 & 0.88 & & \\
\hline \multirow{2}{*}{$\begin{array}{c}\text { Ziyaretçi Memnuniyetinin } \\
\text { Sağlanması }\end{array}$} & Kadın & 103 & 3.51 & 1.07 & \multirow{2}{*}{-0.289} & \multirow{2}{*}{0.773} \\
\hline & Erkek & 175 & 3.55 & 1.09 & & \\
\hline
\end{tabular}

$\mathbf{p}<\mathbf{0 . 0 5}$

Tablo 6' da katılımcıların medeni durumları ile sürdürülebilir turizm tutumları arasında anlamlı farklılık olup olmadığına ilişkin t-testi sonuçları verilmiştir. Yapılan t-testi sonucunda katılımcıların sürdürülebilir turizm tutumları ile medeni durumları arasında anlamlı farklılık bulunmamaktadır ( $>0.05$ ). Dolayısıyla $\mathrm{H}_{2}$ Katılımcıların medeni durum ile sürdürülebilir turizm tutumları arasında anlamlı bir farklılık vardır hipotezi reddedilmiştir.

Tablo 6. Katılımcıların Medeni Durumları İle Sürdürülebilir Turizm Tutumlarına İlişkin t-Testi

\begin{tabular}{|c|c|c|c|c|c|c|}
\hline Faktör & $\begin{array}{l}\text { Medeni } \\
\text { Durum }\end{array}$ & $\mathbf{n}$ & $\overline{\mathbf{x}}$ & S.S. & $\mathbf{t}$ & $\mathbf{p}$ \\
\hline \multirow{2}{*}{ Algilanan Sosyal Maliyetler } & Evli & 130 & 1.98 & 0.85 & \multirow{2}{*}{-1.168} & \multirow{2}{*}{0.143} \\
\hline & Bekar & 148 & 2.13 & 0.84 & & \\
\hline \multirow{2}{*}{ Çevrenin Sürdürülebilirliği } & Evli & 130 & 3.25 & 0.94 & \multirow{2}{*}{0.674} & \multirow{2}{*}{0.501} \\
\hline & Bekar & 148 & 3.18 & 0.90 & & \\
\hline \multirow{2}{*}{ Uzun Dönem Planlama } & Evli & 130 & 3.86 & 0.84 & \multirow{2}{*}{0.690} & \multirow{2}{*}{0.491} \\
\hline & Bekar & 148 & 3.79 & 0.87 & & \\
\hline \multirow{2}{*}{ Algılanan Ekonomik Faydalar } & Evli & 130 & 3.95 & 0.87 & \multirow{2}{*}{-0.659} & \multirow{2}{*}{0.511} \\
\hline & Bekar & 148 & 4.02 & 0.82 & & \\
\hline \multirow{2}{*}{ Toplum Merkezli Ekonomi } & Evli & 130 & 3.48 & 0.85 & \multirow{2}{*}{-0.403} & \multirow{2}{*}{0.687} \\
\hline & Bekar & 148 & 3.51 & 0.74 & & \\
\hline \multirow{2}{*}{$\begin{array}{c}\text { Toplum Katılımın Maksimize } \\
\text { Edilmesi }\end{array}$} & Evli & 130 & 3.48 & 0.86 & \multirow{2}{*}{1.105} & \multirow{2}{*}{0.270} \\
\hline & Bekar & 148 & 3.37 & 0.84 & & \\
\hline \multirow{2}{*}{$\begin{array}{c}\text { Ziyaretçi Memnuniyetinin } \\
\text { Sağlanması }\end{array}$} & Evli & 130 & 3.52 & 1.16 & \multirow{2}{*}{-0.160} & \multirow{2}{*}{0.873} \\
\hline & Bekar & 148 & 3.54 & 1.00 & & \\
\hline
\end{tabular}

Tablo 7'de katılımcıların turizm sektörü deneyimi ile sürdürülebilir turizm tutumları arasında anlamlı farklılık olup olmadığına ilişkin t-testi sonuçları verilmiştir. Yapılan t-testi sonucunda katılımcıların turizm sektörü deneyimi ile ziyaretçi memnuniyetinin sağlanması faktörü arasında anlamlı bir farklılık tespit edilmiştir $(\mathrm{p}<0.05)$. Yerel yönetimin turist memnuniyetini izlemesi ve ziyaretçi memnuniyetini sağlamak için yatırım yapması ifadelerini içeren ziyaretçi memnuniyetinin sağlanması faktörüne sektör deneyimi olmayanlar $(\bar{x}=3.71)$ sektör deneyimi sahip olanlara göre $(\bar{x}=3.44)$ daha yüksek düzeyde katılım göstermişlerdir. $\mathrm{Bu}$ bilgiler doğrultusunda $\mathrm{H}_{3}$ Katılımclların turizm sektöründe deneyimi ile sürdürülebilir turizm tutumları arasında anlamlı bir farklılık vardır hipotezi kabul edilmiştir. 
Tablo 7. Katılımcıların Turizm Sektöründe Deneyimi İle Sürdürülebilir Turizm Tutumlarına İlişkin t-Testi

\begin{tabular}{|c|c|c|c|c|c|c|}
\hline Faktör & $\begin{array}{c}\text { Sektör } \\
\text { deneyimi }\end{array}$ & $\mathbf{n}$ & $\overline{\mathbf{x}}$ & s.s. & $\mathbf{t}$ & $\mathbf{p}$ \\
\hline \multirow{2}{*}{ Algilanan Sosyal Maliyetler } & Var & 182 & 2.05 & 0.88 & \multirow{2}{*}{-0.354} & \multirow{2}{*}{0.723} \\
\hline & Yok & 96 & 2.08 & 0.78 & & \\
\hline \multirow{2}{*}{ Çevrenin Sürdürülebilirliği } & Var & 182 & 3.20 & 0.97 & \multirow{2}{*}{-0.213} & \multirow{2}{*}{0.832} \\
\hline & Yok & 96 & 3.23 & 0.82 & & \\
\hline \multirow{2}{*}{ Uzun Dönem Planlama } & Var & 182 & 3.88 & 0.87 & \multirow{2}{*}{1.321} & \multirow{2}{*}{0.188} \\
\hline & Yok & 96 & 3.73 & 0.84 & & \\
\hline \multirow{2}{*}{ Algılanan Ekonomik Faydalar } & Var & 182 & 4.00 & 0.88 & \multirow{2}{*}{0.409} & \multirow{2}{*}{0.683} \\
\hline & Yok & 96 & 3.96 & 0.77 & & \\
\hline \multirow{2}{*}{ Toplum Merkezli Ekonomi } & Var & 182 & 3.50 & 0.82 & \multirow{2}{*}{0.011} & \multirow{2}{*}{0.991} \\
\hline & Yok & 96 & 3.49 & 0.75 & & \\
\hline \multirow{2}{*}{$\begin{array}{c}\text { Toplum Katılımın Maksimize } \\
\text { Edilmesi }\end{array}$} & Var & 182 & 3.39 & 0.85 & \multirow{2}{*}{-0.843} & \multirow{2}{*}{0.400} \\
\hline & Yok & 96 & 348 & 0.85 & & \\
\hline \multirow{2}{*}{$\begin{array}{c}\text { Ziyaretçi Memnuniyetinin } \\
\text { Sağlanması }\end{array}$} & Var & 182 & 3.44 & 1.16 & \multirow{2}{*}{-2.191} & \multirow{2}{*}{$0.029 *$} \\
\hline & Yok & 96 & 3.71 & 0.89 & & \\
\hline
\end{tabular}

$* \mathbf{p}<\mathbf{0 , 0 5}$

Tablo 8'de katılımcıların eğitim düzeyi ile sürdürülebilir turizm tutumları arasında anlamlı bir farklılık olup olmadığına ilişkin varyans analizi (ANOVA) sonuçları verilmiştir. Katılımcıların eğitim düzeyleri ile sürdürülebilir turizm tutumları arasında anlamlı bir farklılık bulunmadığ tespit edilmiş $(\mathrm{p}>0.05)$ ve $\mathrm{H}_{4}$ Katılımcıların eğitim düzeyi ile sürdürülebilir turizm tutumlar arasında anlamlı bir farklılık vardır hipotezi reddedilmiştir.

Tablo 8. Katılımcıların Eğitim Düzeyi İle Sürdürülebilir Turizm Tutumlarına İlişkin ANOVA Testi

\begin{tabular}{|c|c|c|c|c|c|c|}
\hline Faktörler & & $\begin{array}{c}\text { Kareler } \\
\text { Toplamı }\end{array}$ & sd & $\begin{array}{c}\text { Kareler } \\
\text { Ortalaması }\end{array}$ & $\mathbf{F}$ & $\mathbf{p}$ \\
\hline \multirow{3}{*}{$\begin{array}{l}\text { Algilanan Sosyal } \\
\text { Maliyetler }\end{array}$} & Gruplar aras1 & 1.516 & 4 & 0.379 & \multirow{3}{*}{0.522} & \multirow{3}{*}{0.719} \\
\hline & Grup içi & 198.096 & 273 & 0.726 & & \\
\hline & Toplam & 199.613 & 277 & & & \\
\hline \multirow{3}{*}{$\begin{array}{c}\text { Çevrenin } \\
\text { Sürdürülebilirliği }\end{array}$} & Gruplar aras1 & 2.334 & 4 & 0.583 & \multirow{3}{*}{0.691} & \multirow{3}{*}{0.599} \\
\hline & Grup içi & 230.606 & 273 & 0.845 & & \\
\hline & Toplam & 232.940 & 277 & & & \\
\hline \multirow{3}{*}{$\begin{array}{l}\text { Uzun Dönem } \\
\text { Planlama }\end{array}$} & Gruplar aras1 & 1.111 & 4 & 0.278 & \multirow{3}{*}{0.373} & \multirow{3}{*}{0.828} \\
\hline & Grup içi & 203.041 & 273 & 0.744 & & \\
\hline & Toplam & 204.152 & 277 & & & \\
\hline \multirow{3}{*}{$\begin{array}{l}\text { Algilanan Ekonomik } \\
\text { Faydalar }\end{array}$} & Gruplar aras1 & 3.512 & 4 & 0.878 & \multirow{3}{*}{1.244} & \multirow{3}{*}{0.293} \\
\hline & Grup içi & 192.773 & 273 & 0.706 & & \\
\hline & Toplam & 196.285 & 277 & & & \\
\hline \multirow{3}{*}{$\begin{array}{l}\text { Toplum Merkezli } \\
\text { Ekonomi }\end{array}$} & Gruplar aras1 & 4.994 & 4 & 1.248 & \multirow{3}{*}{2.012} & \multirow{3}{*}{0.093} \\
\hline & Grup içi & 169.438 & 273 & 0.621 & & \\
\hline & Toplam & 174.432 & 277 & & & \\
\hline \multirow{3}{*}{$\begin{array}{l}\text { Topluluk Katılımının } \\
\text { Maksimize Edilmesi }\end{array}$} & Gruplar aras1 & 5.897 & 4 & 1.474 & \multirow{3}{*}{2.077} & \multirow{3}{*}{0.084} \\
\hline & Grup içi & 193.815 & 273 & 0.710 & & \\
\hline & Toplam & 199.712 & 277 & & & \\
\hline \multirow{3}{*}{$\begin{array}{c}\text { Ziyaretçi } \\
\text { Memnuniyetinin } \\
\text { Sağlanması }\end{array}$} & Gruplar aras1 & 4.434 & 4 & 1.109 & \multirow{3}{*}{0.950} & \multirow{3}{*}{0.435} \\
\hline & Grup içi & 318.491 & 273 & 1.167 & & \\
\hline & Toplam & 322.925 & 277 & & & \\
\hline
\end{tabular}

p $<0.05$ 
Tablo 9'da katılımcıların gelir düzeyi ile sürdürülebilir turizm tutumları arasında anlamlı bir farklılık olup olmadığına ilişkin varyans analizi (ANOVA) sonuçları verilmiştir. Katılımcıların gelir düzeyleri ile sürdürülebilir turizm tutum faktörlerinden ziyaretçi memnuniyetinin sağlanması faktörü arasında anlamlı bir farklılık tespit edilmiştir $(\mathrm{p}<0.05)$.

Tablo 9. Katılımcıların Gelir Düzeyi İle Sürdürülebilir Turizm Tutumlarına İlişkin ANOVA Testi

\begin{tabular}{|c|c|c|c|c|c|c|}
\hline Faktörler & & $\begin{array}{l}\text { Kareler } \\
\text { Toplamı }\end{array}$ & sd & $\begin{array}{c}\text { Kareler } \\
\text { Ortalaması }\end{array}$ & $\mathbf{F}$ & $\mathbf{p}$ \\
\hline \multirow{3}{*}{$\begin{array}{l}\text { Algilanan Sosyal } \\
\text { Maliyetler }\end{array}$} & Gruplar arası & .391 & 4 & 0.098 & \multirow[t]{3}{*}{0.134} & \multirow[t]{3}{*}{0.970} \\
\hline & Grup içi & 199.222 & 273 & 0.730 & & \\
\hline & Toplam & 199.613 & 277 & & & \\
\hline \multirow{3}{*}{$\begin{array}{c}\text { Çevrenin } \\
\text { Sürdürülebilirliği }\end{array}$} & Gruplar arası & .605 & 4 & 0.151 & \multirow[t]{3}{*}{0.178} & \multirow[t]{3}{*}{0.950} \\
\hline & Grup içi & 232.335 & 273 & 0.851 & & \\
\hline & Toplam & 232.940 & 277 & & & \\
\hline \multirow{3}{*}{$\begin{array}{l}\text { Uzun Dönem } \\
\text { Planlama }\end{array}$} & Gruplar arası & 1.871 & 4 & 0.468 & \multirow[t]{3}{*}{0.631} & \multirow[t]{3}{*}{0.641} \\
\hline & Grup içi & 202.282 & 273 & 0.741 & & \\
\hline & Toplam & 204.152 & 277 & & & \\
\hline \multirow{3}{*}{$\begin{array}{c}\text { Algılanan Ekonomik } \\
\text { Faydalar }\end{array}$} & Gruplar arası & 1.739 & 4 & 0.435 & \multirow[t]{3}{*}{0.610} & \multirow[t]{3}{*}{0.656} \\
\hline & Grup içi & 194.546 & 273 & 0.713 & & \\
\hline & Toplam & 196.285 & 277 & & & \\
\hline \multirow{3}{*}{$\begin{array}{l}\text { Toplum Merkezli } \\
\text { Ekonomi }\end{array}$} & Gruplar arası & .456 & 4 & 0.114 & \multirow[t]{3}{*}{0.179} & \multirow[t]{3}{*}{0.949} \\
\hline & Grup içi & 173.976 & 273 & 0.637 & & \\
\hline & Toplam & 174.432 & 277 & & & \\
\hline \multirow{3}{*}{$\begin{array}{l}\text { Topluluk Katılımının } \\
\text { Maksimize Edilmesi }\end{array}$} & Gruplar arası & 2.783 & 4 & 0.696 & \multirow[t]{3}{*}{0.964} & \multirow[t]{3}{*}{0.427} \\
\hline & Grup içi & 196.929 & 273 & 0.721 & & \\
\hline & Toplam & 199.712 & 277 & & & \\
\hline \multirow{3}{*}{$\begin{array}{c}\text { Ziyaretçi } \\
\text { Memnuniyetinin } \\
\text { Sağlanması }\end{array}$} & Gruplar arası & 14.053 & 4 & 3.513 & \multirow[t]{3}{*}{3.105} & \multirow[t]{3}{*}{$0.016 *$} \\
\hline & Grup içi & 308.872 & 273 & 1.131 & & \\
\hline & Toplam & 322.925 & 277 & & & \\
\hline
\end{tabular}

*p $<\mathbf{0 . 0 5}$

Varyans analizi sonrası tespit edilen anlamlı farklılı̆̆ın hangi gruplar arasında olduğunu belirlemek için çoklu karşılaştırma testlerinden Bonferroni testi sonucuna göre 1500 TL'ye kadar gelire sahip olanlar $(\overline{\mathrm{x}}=3.73), 1501-2000 \mathrm{TL}$ aras1 gelire sahip olan kat1limc1lara $(\overline{\mathrm{x}}=3.18)$ göre ziyaretçi memnuniyetinin sağlanması faktörüne daha yüksek düzeyde katılım göstermişlerdir. $\mathrm{Bu}$ bilgilerden hareketle $\mathrm{H}_{5}$ Katılımcıların gelir düzeyleri ile sürdürülebilir turizm tutumları arasında anlamlı bir farklılık vardır hipotezi kabul edilmiştir.

\section{SONUÇ VE ÖNERILER}

Sürdürülebilir turizm, turizmin neden olduğu çevresel ve sosyal etkilerin en aza indirilmesi, yerel halkın turizm endüstrisinden ekonomik kazancının en üst düzeye çıkarılması, yerel halk ile turist etkileşiminin arttırılması ve yerel halkın turizm planlamasına dahil edilmesinde kullanılabilmektedir (Patterson, 2016, s. 5). Sürdürülebilirlik, turizmin olumsuz etkilerini en aza indirmek ve uzun dönemli başarı sağlayabilmek için gerekli ve iyi bir seçenektir. Yerel halk turizm destinasyonlarında sürdürülebilir kalkınmada önemli role sahiptir (Ayazlar \& Ayazlar, 2016). Fethiye ilçe merkezinde yaşayan yerel halk ile gerçekleştirilen bu araştırmada katılımcılar sürdürülebilir turizmde kendilerine çok fazla rol biçmemektedirler. Daha çok kamu kurumları ve turizm işletmelerini sorumlu görmektedirler.

Genellikle sürdürülebilir turizmde ilk akla gelen çevresel etkiler olsa da aslında sosyal maliyetlerde son derece önemlidir. Turizmin geliştiği bölgede sosyal etkilerinin ölçülmesi önemli olduğu kadar zor bir süreçtir. Düzenli olarak ölçülmesi; turist-yerel halk arasındaki sorunların 
önleyici tedbirinin alınması için gereklidir. Fethiye önemli sayıda turisti ağırlayan bir turizm şehridir. Bu açıdan turistlerin ve turistik etkinliklerin yerel halkın sosyal dokusu üzerinde bıraktığ etkilerin düzeyi tespit edilmelidir. Yerel halkın turistlere olan davranışlarını belirleyebilecek önemli bir faktör olan algılanan sosyal maliyetlerin Fethiye'de negatif etkilerinin görülmediği araştırmanın sonucunda ortaya çıkmıştır. Turizmin ortaya çıarabileceği ve arttırabileceği kalabalıklaşma, yaşam kalitesinde bozulma, rahatsızlık gibi olayların araştırma sonucunda Fethiye'de çok düşük düzeyde gerçekleştiği ifade edilebilir. Bu durum, turistik tesislerin Fethiye ilçe merkezinin dışında Göcek, Ölüdeniz, Hisarönü, Ovacık bölgesinde daha çok olmasından ve turistlerin büyük kısmının bu bölgelerde yoğunlaşmasından kaynaklanmaktadır.

Çevrenin sürdürülebilirliği, sürdürülebilir turizmde en önemsenen alanların başında gelmektedir. Turizm çoğunlukla doğal kaynak temelli bir olaydır. Çevreye verilen veya verilebilecek zararların tespit edilip buna uygun önlemler geliştirilmesi çevrenin daha sürdürülebilir olmasını sağlar. Bu faktör altında yöneltilen ifadelere katılım ortalamaları orta düzeyde gerçekleşmiştir. Bu sonucun ortaya çıkmasının farklı sebepleri olabileceği gibi bunlardan birisi ekonomik fayda için çevrenin göz ardı edilmesi olabilir. Turizmde sağlıklı gelişim ve büyüme ancak uzun dönemli planlarla mümkündür. Uzun dönem planlama sürdürülebilir turizm için gereken hususlardandır. Fethiye için bu faktör altında verilen ifadelere araştırmaya katılanlar orta düzeyde katılım göstermişlerdir.

Turizmin geliştiği bölgelerde üzerinde en çok durulan konulardan birisi hiç şüphesiz ekonomik faydadır. Araştırmaya katılanlar turizmin algılanan ekonomik faydasına ilişkin yüksek düzeyde katılım göstermişlerdir. Turizmin ekonomiyi çeşitlendirdiği, yeni istihdam alanları açtı̆̆ ve bölge ekonomisine önemli katkılar yaptığını düşünmektedirler. Literatürde de (Assente vd., 2012; Gündüz, 2018; Güneş \& Alagöz, 2018; Dündar \& Ünlüönen, 2018) yerel halkın turizmden beklentilerinin daha çok ekonomik faydasına yönelik olduğu şeklindedir. Elde edilen bu sonuç literatür ile örtüşmektedir. Toplum merkezli ekonomi açısından değerlendirildiğinde turizmin doğrudan Fethiye ve çevresinde oluşturduğu ekonomik katk1 seviyesi algılanan ekonomik faydalara göre düşük bir seviyededir. Turizm sektörünün doğrudan Fethiye'ye verdiği ekonomik katkı seviyesi ifadelerine (orta düzeyde) kararsız bir tutum sergilemişlerdir.

Toplum katılımın maksimize edilmesi faktöründe elde edilen sonuçlarda orta seviyelerde bir katılım ortalamasının gerçekleştiği söylenebilir. Yerel halkın aktif olarak turizmle ilgili süreçlerin içinde yer alması sağlıklı bir turizm gelişimi için önemlidir. Fethiye'de ekonomik anlamda daha çok tarım ve turizmden gelir elde edilmektedir. Yerel halkın büyük bir çoğunluğu tarım ve turizmi birlikte yürütmekte ve dolaylı yönden aktif olarak turizmde çalışmaktadır.

Ziyaretçi memnuniyetinin sağlanması ve izlenmesi bir turizm destinasyonu için başarının veya başarısızlı̆̆ın göstergelerinden birisi olarak gösterilebilir. Bu faktör altında yöneltilen ifadelere ilişkin olarak katılım ortalamalarının ortanın üstü yükseğe yakın olduğu söylenebilir. Yerel yönetimlerin turist memnuniyetini sağlama adına memnuniyetin takip edilmesi ve olumlu izlenimleri arttırması gibi faaliyetlere yönelmesi gerekmektedir. Burada ziyaretçi memnuniyetinin arttırılabilmesi için Fethiye'de yaşayan yerleşik yabancılardan faydalanılabilir. Özellikle yerleşik yabancıların kurdukları sivil toplum kuruluşları ziyaretçi memnuniyetinin izlenmesinde etkin rol oynayabilir.

Araştırmada test edilen hipotezlere ilişkin sonuçlara bakıldığında katılımcıların cinsiyet, medeni durum ve eğitim durumlarına göre sürdürülebilir turizm tutumları arasında anlamlı bir farklılık yoktur. Sadece katılımcıların turizm sektörü deneyimi ve sahip olunan gelir düzeyi ile sürdürülebilir turizme ilişkin tutumları arasında farklılıklar tespit edilmiştir.

$\mathrm{Bu}$ araştırmada elde edilen bulgular 2017 yılında Fethiye ilçe merkezinde yaşayan ve araştırma örnekleminde yer alan yerel halkın görüşleri ile sınırlıdır. Turizm paydaşlarından sadece biri olan yerel halkın tutumunun sürdürülebilir turizm gelişiminin değerlendirilmesi için yeterli değildir. Tüm paydaşların sürdürülebilir turizme katılımı esastır. Dolayısıyla daha sonra yapılacak çalışmalar yerel halk ile birlikte diğer turizm paydaşlarının katılımını sağlayacak şekilde 
yapılabilir. Kamu kurumları ve sivil toplum kuruluşlarının ilçedeki turizmin gelişmesine katkı sunmaları için etkin ve birlikte çalışmaları önemlidir.

\section{KAYNAKÇA}

Altıntaş, V. (2010). Turizm gelişiminin yerel halkn yaşam kalitesi üzerine etkileri: Alanya bölge modeli. Yayınlanmamış doktora tezi, Akdeniz Üniversitesi, Sosyal Bilimler Enstitüsü.

Assante, L. M., Wen, H. I. \& Lottig, K. J. (2012). Conceptualization of modeling resident attitudes on the environmental impacts of tourism: A case study of Oahu, Hawaii. Tourism Planning \& Development, 9 (2), 101-18.

Ayazlar,R. \& Ayazlar, G. (2016).Residents' tourism support behaviour: The role of sustainable tourism attitude. Enlightening tourism. A Path Making Journal, 6(2), 124-149.

Büyüköztürk, Ş. (2010). Sosyal bilimler için veri analizi el kitabı. 11. Baskı, Ankara: Pegem Akademi Yayıncilik.

Can, A. (2018). SPSS ile bilimsel araştırma sürecinde nicel veri analizi. 6. Baskı, Ankara: Pegem Akademi Yayıncilik.

Choi, H. C. \& Murray, I. (2010). Resident attitudes toward sustainable community tourism. Journal of Sustainable Tourism, 18(4), 575-594.

Cottrell, S. P., Vaske, J. J. \& Roemer, J. M. (2013). Resident satisfaction with sustainable tourism: The case of Frankenwald Nature Park, Germany. Tourism Management Perspectives, 8, 42-48.

Çetin Gündüz, H. \& Nalbantoğlu Yılmaz, F. (2016). Lise öğrencilerinin kariyer kaygılarını belirlemeye yönelik ölçek geliştirme çalışması. Mersin Üniversitesi Eğitim Fakültesi Dergisi, 12(3), 1081022.

Dağlı, Z. (2018). Sürdürülebilir turizmin gelişimine yönelik yerel halkın tutumlarını incelemeye ilişkin bir araştırma: Akçakoca destinasyonu. Seyahat ve Otel Iş̧letmeciliği Dergisi, 15(3), 603-619.

Duran, E. (2013). Yerel halkın sürdürebilir turizm gelişimine yönelik tutumları; Bozcaada örneği. Uluslararası Hakemli Beşeri ve Akademik Bilimler Dergisi, 3(2), 76-94.

Dündar, Y. \& Ünlüönen, K. (2019). Neo-kolonyalizm aracı olarak kitle turizminin etkileri üzerine bir araştırma. Journal of Tourism and Gastronomy Studies, 7 (3), 2066-2107.

FETAV (2018). Fethiye Turizm Tanıtım Eğitim Kültür ve Çevre Vakfi, Retrieved from: https://www.haberturk.com/mugla-haberleri/63220216-fethiyenin-yerlesik-yabancilari. Erișim tarihi: 22 Subat 2019.

Fethiye Belediyesi (2017). Retrieved from http://www.fethiye.bel.tr/, Erişim tarihi: 20 Ocak 2019

Garrod, B \& Fyall, A. (1998). Beyond the rhetoric of sustainable tourism. Tourism Management, 1(3), 199212.

Gündüz, S. (2018). Yerel halkın turizm algısını belirlemeye yönelik alternatif bir ölçek geliştirme: Karataş destinasyonu örneği. Journal of Yaşar University, 13(52), 343-357.

Güneş, E. \& Alagöz, G. (2018). Yerel halkın turizm algısı: Erzincan'da bir araştırma. Iğdır Üniversitesi Sosyal Bilimler Dergisi, 15, 409-442.

Huayhuaca, C., Cottrell, S., Raadik, J., \& Gradl, S. (2010). Resident perceptions of sustainable tourism development: Frankenwald Nature Park, Germany. International Journal of Tourism Policy, $3(2), 125-141$.

Joshi, R., \& Dhyani, P. P. (2009). Environmental sustainability and tourism-1mplications of trend synergies of tourism in Sikkim Himalaya. Current Science, 1(1), 33-41.

Kayış, A. (2010). Güvenilirlik Analizi. In Ş. Kalaycı (Ed.), SPSS uygulamalı çok değişkenli istatistik teknikleri (pp. 401-419), 5. Baskı, Ankara: Asil Yayın Dağıtım. 
Khalid, S., Ahmad, M. S., Ramayah, T., Hwang, J. \& Kim, I. (2019). Community empowerment and sustainable tourism development: the mediating role of community support for tourism. Sustainability, 11(22), 1-14.

Kültür ve Turizm Bakanlığı (2017). Retrieved from, www.kultur.gov.tr. Erişim tarihi: 22 Şubat 2019.

Lee, T. H. (2013). Influence analysis of community resident support for sustainable tourism development. Tourism Management, 34, 37-46.

Liu, Z. (2003). Sustainable tourism development: A critique. Journal of Sustainable Tourism 11, 459-475.

McCaughey, R., Mao, I. \& Dowling, R. (2018). Residents' perceptions towards cruise tourism development: The case of Esperance Western Australia. Tourism Recreation Research, 43(3), 403-408.

Muğla İl Kültür ve Turizm Müdürlüğü (2017). Retrieved from, www.muglakulturturizm.gov.tr. Erişim tarihi: 22 Şubat 2019.

Muresan, I., Oroian, C., Harun, R., Arion, F.H., Porutiu, A., Chiciudean, G.O., Todea, A. \& Lile, R. (2016). Local residents' attitude toward sustainable rural tourism development. Sustainability, 8(100), $1-14$.

Patterson, C. (2016). Sustainable tourism: Business development, operations and management. stanningley. Champain: Human Kinetics.

Sangkakorn, K. \& Suwannarat, S. (2013). Local people participation in tourism development: The case study of Chiang Mai, 2nd Conference on Asian Economic Development, Chiang Mai University. in Faculty of Economics, (August 14).

Sirakaya-Türk, E. Ekinci, Y. \& Kaya, A. G. (2008). An examination of the validity of SUSTAS in crosscultures. Journal of Travel Research, 46, 414-421.

Sonuç, N. (2014). Sürdürülebilir Turizm: Tanımı ve İçeriği. In M. Kozak (Ed.), Sürdürülebilir turizm (pp. 13-28), Ankara: Detay Yayıncılık.

Tabachnick, B. G. \& Fidell, L. S. (2013). Using multivariate statistics. Boston: Pearson.

TÜİK (2020). Türkiye İstatistik Kurumu, Retrieved from, www.tuik.gov.tr. Erişim tarihi: 22 Ocak 2020.

TÜRSAB (2017). Türkiye Seyahat Acentaları Birliği, Retrieved from, www.tursab.org.tr. Erişim tarihi: 22 Şubat 2019.

United Nations Environment Programme (UNEP), World Tourism Organisation (WTO). (2005). Making tourism more sustainable: A guide for policy makers. Madrid: World Tourism Organisation.

UNWTO (2019). Sustainable Development. (Online) Retrieved from, https://www.unwto.org/sustainabledevelopment. Erişim tarihi: 09 Ocak 2020. 